\title{
Armed groups: problems of theory and classification
}

\author{
Andrei Miroiu
}

\begin{abstract}
:
This paper argues in favor of a theory and classification of armed groups that sets them at the center of political and social sciences. Starting from the problem of order, it argues that without armed groups one cannot understand how stable societies form, function and reproduce themselves. It challenges the preeminence of concepts such as class and gender, which are seen as depicting later-formed social structures. It proposes a classification of armed groups based on their permanent or impermanent character, as well as the reasons for using violence, mostly extractive and ideological. The article also discusses armed groups operating within the state.
\end{abstract}

\section{Keywords:}

armed groups; states; political science; social sciences; violence; social order 


\section{The problem of armed groups}

It is perhaps natural in an age when new technologies and gadgets emerge almost on a daily basis to assume that unexpected social events are also new. Both theorists and practitioners reacted this way in recent years when armed groups (AGs) contested with remarkable success governmental structures in the Horn of Africa, the mountains of Hindu Kush, Northern Mesopotamia and Eastern Syria, the upper banks of the Niger or the area of the Great Lakes of Africa (Kaplan: 2002), (Kilcullen: 2015), (Layton: 2015). Because these groups did not necessarily aim at the usurpation of political power and often did not try to establish state-like structures, they were assumed to be part of a new set of social phenomena unleashed by the end of the Cold War, globalization and the breakdown of post-imperial order in Africa or the Middle East (Raufer: 1999), (Krahmann: 2005).

Considerable theoretical effort was spent in understanding the new movements from this perspective, as an effect of contemporary historical, economic and social processes. The character of novelty was presumed and seldom justified. At most, these movements were sometimes assumed to be part of the historical process of the contestation of the Western hegemonic order begun by regional movements during and after the Second World War (Lutz \& Lutz: 2013). In this case, a certain historical method was used in understanding them, but even when this perspective was embraced they were considered fundamentally a modern phenomenon (Nagl: 2002), (Vinci: 2008), (Boot: 2013). More often than not, however, they are assumed to be extremely new, products of recent developments and therefore necessitating novel, innovative approaches, both theoretical and practical (Army, U.S.: 2006), (Kilcullen: 2010). Enormous energies and sums of money were spent on mostly sociological and anthropological surveys and research trips and in most of these cases the efforts only served to highlight the diversity of the subjects of the research (Kelly: 2010), (Porch: 2013). The result was hardly unexpected given the methodology of these social science approaches and the hypothesis of novelty underlining present-day research.

However, an alternative perspective, grounded in political theory and the longterm historical study of human political communities points out in a different direction and leads to other theoretical and practical consequences. This perspective assumes that 
the basis of community and politics is order. Without order and relatively peaceful internal interactions of a personal, economic and cultural nature, a community, no matter its size, cannot function. This is not to say that violence cannot permeate the life of a community. All communities witness at the very least some degree of verbal, symbolic or physical violence between its members (Kalyvas: 2006). However, community life and the existence of a society is threatened, if not made impossible when the level of violence threatens the order necessary for the continuation of the basic social interactions. This is the reason why order is the essence that underpins any stable, long-lasting groups of humans and as a matter a fact groups of many other animals.

But who underpins order? Who creates it and guarantees it at a fundamental level? Laws, political parties, economic elites, social norms and mores, cultural practices, all reinforce and support order and the continuation of communities. They do create the conditions for the perpetuation of order, but by themselves they do not create order, nor can they defend it against strong, determined groups meaning to defy it. It is armed force and armed superiority that creates order and ultimately the strongest armed groups are the defenders of order in any human community (Hobbes: 1983 (1651)). This is less of a moral statement and more of a statement of fact. As societies grow more complex and peaceful, as prosperity permeates large categories and vital problems such as access to shelter, food, water, clothing and sexual partners become less stringent, as social and cultural norms become accepted or imposed into acceptance by large categories of the population, the reality that order is created and underpinned by brutal force is often obfuscated. Social complexity seems to breed complex, sometimes arcane social and political explanations, ascribing the formation of order to human nature, the divine laws, or inherent, deep social and economic structures (Weber: 1978). To a certain extent, some of these theoretical concepts can explain the reality of complex societies, but they fail to explain the basis on which all communities are formed and fundamentally rest: fear of the power and violence of an armed group.

If this perspective holds water, it would throw an entirely different light on the AGs that pose so many challenges to the continuation of politics as we know it in many areas of Asia, Africa and Latin America. At its fundamental level, order does not necessarily imply a continuous historical process towards state formation. A society can easily exist being ruled not by a central government extracting taxes and providing common goods, but by multiple layers of symbolic and practical power. The sacredness of the king, the complete cultural dominance of the Catholic Church, the economic 
power of the great magnates and the urban guilds ruled medieval Western Europe (Bloch: 1940), (Le Goff: 1964). Order, as much as it existed, was guaranteed by the armed retainers of the feudal lords, sometimes gathered under the banners of a king, pope or emperor. The Native American societies of the Great Plains or Texas were ruled by complex groups of wise members of the tribes, collections of legends and rituals and the specific economic rules of exchange. Order was, however, guaranteed by the bands of young warriors (Hämäläinen: 2008), (Gump: 2016). There is nothing to say that these societies, or others, should have necessarily evolved in the direction of nation states. Indeed, some of them never underwent the process until forcefully occupied. Even when this happened and these communities became notionally subjected to a foreign overlord, in many of them armed groups continued to assert their claim in creating order in certain areas or in segments of society. The case of India's northwestern frontier during the times of the British Raj is a notorious example in this regard (Darwin: 2009), but non-western empires such as the Ottomans also had entire regions under their nominal control that were actually ruled by local AGs, especially in North Africa (Mantran: 1989), (Inalcik: 2013).

Therefore, there is no particular reason to view these AGs through the lens of the national state or the presumed inevitable process of national state formation. Indeed, the very fact that in many of the current analyses these groups are called "non-state actors" is a problem by itself (Miroiu, Ungureanu: 2015). These groups should not be seen in this light, even when they sprung from the ashes of national states or have national states as opponents. Indeed, they exist at a more fundamental level of politics and basic social interaction, which is that of the contestation and creation of basic order. These groups also exist within the state, as police, armed forces, intelligence services or local militias and criminal groups influencing or even organizing human activity in a certain geographic or economic region. When they exist inside the state and while not in conflict, they create the order that makes the state possible. When outside the state, they exist at the primary level of human social interaction. One does not need the state, or concepts such as class, race, gender, social or cultural stratification to understand the essence of these groups, as they are united at a more basic level of politics, which is insuring survival and domination.

If this perspective were to be embraced, the consequences would be manifold, be they theoretical or practical. The conceptual consequences would be a reset of the fundamentals of social science both notionally beyond and chronologically before the 
state or other conceptual building blocks. Historians, sociologists and political scientists would need to remove the state/class/race/gender-tinted glasses that color their view of the beginning and basis of politics and replace them with a consideration of the problem of order.

\section{Understanding armed groups}

At their fundamental level, armed groups are defined just by their numbers, possession of weapons and the willingness and ability to use armed violence to create, defend or contest order on a certain territory or in a certain social segment. Unlike the state and at a more subtle level, they do not need to be territorial, as order itself is more than just territorial. For understanding particular, historical armed groups, notions of social and gender composition as well as cultural or ideological persuasions could be necessary (Marx, Engels: 2002), (Engels: 2010), (Scott: 1986), (Anderson, Zinsser: 1989). To understand their basic social role, one can dispense with these perspectives.

Practically, political leaders would have to choose between the time-tested approaches, sometimes successful, often not, of accepting and imposing the modern state and the associations of states as the only possible and legitimate authorities in the world. They would have to ponder the co-existence of state with regions dominated by other actors - all of them underpinned by armed groups. They would have to consider whether the existence of these regions poses an existential threat to their nations and the world system, as we know it. And political leaders of democratic nations will also be confronted by the idea that it may be someone's right to live in a community which is not defined by a nation-state but rather by an armed group. This idea in itself has the potential to rewrite a considerable section of political and constitutional theory, as we know it and raises interesting questions for learned individuals everywhere.

Indeed, to a certain degree states already do coexist with armed groups, willingly or not, consciously or not. Vast areas of central Africa, Southeast and central Asia were always ruled by local armed groups, even in colonial times, when in many areas the British imperial red, coloring a vast part of any world map, was just a political and scientific convention (James: 1994). In Latin America even relatively modern states virtually renounced control over parts of their territory in favor of violent or even nonviolent militias or drug-lords (Bracamonte, Spencer: 1995), (Priestland: 2009). Inside society, segments of even advanced, democratic Western nations were at one time or the 
other controlled not by the authorities, but by armed and violent criminal groups (Dickie: 2014). While entirely possible and factual, this coexistence of multiple forms of creating social and political order is obfuscated by the states and political elites, who tend to claim sole legitimacy, usually through elections. But legitimacy and authority is formed in many ways, through blood ties, charisma, and provision of counseling and economic subsistence (Weber: 1978). There is hardly any historical truth or justice behind the idea that legitimacy can only come through elections.

This view also highlights another important consequence. AGs were, are and will continue to be a fundamental component of social and political organization, as they serve a basic function of any said organization. While the removal (by states or other armed groups) of some particular armed group from a region or segment of society is entirely possible and perhaps sometimes even desirable, the problem itself remains and transcends all cleavages that separate any society from another. At the core of any society or human permanent gathering is at least one AG. We will have to admit this reality, adapt our theories and practice, and move on.

\section{Classifying armed groups}

While social complexity increases with demographic growth, economic expansion and the continuous creation of social norms, certain basic functions remain the same. As armed groups tend to cater to particular, old and somehow perennial social functions, it is not eminently necessary to classify them by historical period, although it might seem tempting.

Indeed, certain types of non-state armed groups may seem to be specific to particular historical periods and in a sense to be entirely contained by them. One could look for instance at the military orders during the time of the Latin Kingdom of Jerusalem (and before the Order of the Hospital became its own near-state in Rhodes at the beginning of the $14^{\text {th }}$ century). It would appear that they took specific forms and a unique outlook based on the local and temporal conditions. But this would be to succumb to ritual, attire and to taking a bit too seriously medieval institutional regulations and relations with the pope or the local suzerain. In essence the military orders were fulfilling two roles many other armed groups did and still do: they offered an additional military force to the existing, lay forces of the Kingdom and the other Latin states of the Outremer and also provided private military protection to pilgrims 
visiting the Holy Sites (Riley-Smith: 1967), (Tyerman: 2006). Not one of these roles is specific or historically contained.

AGs operate at the elementary level of power - that of coercing someone's will by force or the threat of violence. While they may acquire other roles, in many cases related to the provision of social services, they are not part of their essence. A militant group can provide food and medicine to a beleaguered community (Biro: 2010). So can a government, a humanitarian foundation, a businessman or an international aid organization. An armed group may instil loyalty, create preferred behavioural patterns and influence folklore. So can a soccer club. While the additional roles an armed group takes or has it thrown upon itself are interesting and could make the bread and butter of anyone working for and on them, they are not defining of their nature and therefore can not help in their classification.

As has been previously argued, AGs exist before the state, simultaneously with it, both outside and inside the state or indifferent to the state altogether. They can assume various positions in relation to the state: they can be organs of the state such as the army, police, paramilitary units of the secret services; they can be gangster groups which operate inside a state but in no particular relation to it; they can be local militias regulating local affairs (Underwood and Smith: 2008). While the relation with the state and especially governments leads us closer to the essence and functioning of armed groups, by itself it is not a defining feature of AGs and cannot be used for a systematic classification of them.

The defining characteristic of an armed group is its ability to use and threaten the use of armed, decisive violence against its opponents. It follows therein that there are two ways in which a classification of armed groups can be done at a consistent and fundamental level. The first involves the sustainability of this threat and use of violence and the second would be the purpose for which violence is threatened or used.

The first criterion may seem somehow fleeting, but is of the essence: an armed group can be a permanent or impermanent social gathering. This feature needs to be understood in the following way: it does not refer to the permanence of the carrying and use of weapons, but rather to the permanence of the gathering as an armed group. For instance, the fact that a gangster group can refrain for a significant period of time from the use and threat of violence and even from the carrying of weapons does not mean that during such a period it is not an armed group, much like an army is no less of an armed group in the extended periods of peace. As their social purpose is permanent, they 
remain AGs even in such instances. Other social gatherings, for instance, can be temporary AGs, for instance local defence militias that are activated in case of need. They are AGs only for the duration of the emergency. They do not posses coherence outside the emergency and their social purpose is limited temporally and functionally. The same can be said, with varying degrees of reliability, for the defensive or offensive structures of pre-state sedentary communities: their AGs were more or less impermanent. Even war bands can be said to be temporary AGs, even if all the members stayed the same from one warpath to another. In this, they differ from the type of AGs that generate order in states, in the sense in which they do generate order but are impermanent. The police have to continually be on the streets to maintain order. A war band does not. In this, they are closer to the type of order maintained by a gangster group, with the provision that gangster groups are permanent armed groups whereas most war bands are not.

The second criterion divides AGs by the purpose for which violence or the threat of violence is used. It has to be said from the beginning that the classification deriving from this feature cannot be taken as dividing armed groups into rigid categories. Indeed, for some these uses may be overlapping and it would be difficult to place some groups in any specific category. Furthermore, at certain points in their existence, certain historic AGs have jumped from one category into another or had to juggle many of them simultaneously. Certain criminal armed groups can be taken to be purely economic structures. But they can also be seen as cultural, identity-based gatherings defending a certain type of honour or the traditions of an ethnic minority perceived to be slighted by an indifferent government and a racist majority. Guerrilla groups, which can be thought of as either sovereignty or legitimacy contestants, have sometimes shifted to purely economic activities, either to finance their political activities or having entirely turned into gangster empires. In other cases they have been more active as social controllers in enforcing certain social norms that the government is too soft on, such as drug trafficking, or does not consider illegal, such as sexual practices.

But this ambiguity should not dissuade us from using the purpose of the use and threat of violence as a defining criterion for the classification of AGs (Schnekener: 2009).

There are three types of reasons, two major and one subsidiary for the use of violence by AGs. The subsidiary reason, somehow strangely, is political and we discuss it here when it is squarely situated inside states or organized, perhaps sometimes 
peaceful communities. But in general the term political should not be used without a certain apprehension. AGs are operational units at such a basic level that they precede politics in chronological terms. They also transcend politics understood as a peaceful activity, through their centrality in war. AGs form the conditions for peace and the ingredients for war. War, or violent conflict is the norm of interaction and peace is always just an armed armistice.

First, the main type of "political" AGs could be seen to be those using violence to guarantee stability. They are the AGs of the state or, in some instances, the AGs that are the state. They encompass in many instances the army, police, state militias and paramilitaries (such as the party militias of a ruling political party or the armed components of the secret services).

Secondly, an armed group uses violence to contest the ability or rights of one particular elite to rule one said state or community. In this case, the armed group does not contest the existence of the community as such, perhaps not even most of its fundamental rules (Wilkinson: 2015), though this interferes in some cases with the first of the major reasons for the use of violence, explained in the following paragraphs. The armed group substantially requires just the modification of some of the policies of the ruling group or, at most, the replacement of some individuals and rules of government with individuals and rules agreed by the group. In this case we can sum up this case as involving legitimacy-contestants. Many civil wars, skirmishes and acts of political terrorism fall in this category. To a certain extent, most dynastic contests, the civil wars of Ancient Rome and even some modern revolutions fall in this category (Syme: 2002).

Thirdly, an armed group uses violence to contest the control of a ruling group over a particular stretch of territory. Though they can again be revolutionary in nature and they can be from inside or the outside of the political boundaries of a community, the AGs in this case have as a fundamental goal to detach a piece of territory from a given political community, either to rule it independently or to glue it to another, preexisting, political body. In this case we are talking about sovereignty-contestants. Many ethnic militias, anti-colonial fighters and other pro-independence movements fall into this category, but so did the American confederates or the Austrian fascists of the late 1930s.

The first of the major reasons could be labelled as ideological/religious. The AGs that fall in this category challenge the rules of repartition (mostly, of power and/or resources) and the rules of behaviour in a community. It is an interesting observation 
here that class, gender or race-based conflicts and groups fall in both types of rulescontestation.

The duality of definition is, of course, contestable. Why indeed add the "religious" as a distinct category or sub-category? At their core, the groups operating with these reasons are doing the exact same thing, which is contesting the fundamental social, economic and ethical rules on which a particular community is based and seeking to replace them with an alternative code which they (the groups) consider correct, more appropriate or simply ethical. So functionally the two types are largely indistinct. The sole difference is to be found in the source from which these groups derive their beliefs. The religious groups extract theirs from a particular understanding or communication with a trans-natural being or sets of being, whereas the others, commonly called ideological with a late $18^{\text {th }}$ century term, are deriving their beliefs from supposedly rational or ethically-coherent social and political views. As behaviourally and to a large extent ontologically the two types of intellectual legitimation of violence are largely indistinct, the sole reasons we keep the duality of the division (ideological/religious) are historical and to allow those working on particular armed groups to create more detailed sub-distinctions. Again, the types themselves of armed groups do not interest us here and are somehow inconsequential once we can assert that one particular group is a member of one of the categories.

One aspect that has been alluded to before needs to be better understood here. The ideological/religious groups often overlap the political-contestant groups. While indeed in some cases, particularly of dynastic or tribal conflict the political-contestant groups are distinct and their motivations for the use of violence are separate, in most other cases they are just subgroups of the ideological/religious divide. Even militant independence movements are most of the time dominated not by the sovereigntycontestant impulse, which is just an action-trigger, but by larger nationalist or confessional-based convictions. Therefore it is to be understood that the politicalcontestation criterion is seldom independent and its use in classification needs to be treated carefully, always considering the possibility of the pre-eminence of the ideological/political impulse.

The second major reason for the use or threat of violence by AGs is squarely economical. The economic criterion is fundamentally about extraction and redistribution (which is to be understood as extraction from producers/owners followed by redistribution to the members of the groups or to other communities). 
The main division that needs to be discussed here is between external and internal economically motivated AGs. The external groups operate from beyond the established and perhaps recognised boundaries of one political community. The groups that tend to fall in this category are raiding parties and warlords, of which the Native American groups of old as well as the Germanic tribes operating against the northern limes of the Roman Empire in the second and third centuries of the Christian era are good examples (Heather 2009), though contemporary Africa can boast of many similar examples, for instance in the large region that used to be known in toto as the Sudan.

There are also three types of permanent extraction in which the external economic groups can engage. First would be a permanence of extraction with continuity, in which case a raiding party transforms itself into a ruling group, thus transitioning from external to internal economic armed group. Secondly there is the classical permanence of extraction without continuity, best exemplified by raids and the regular demand of tribute. Thirdly, the extraction is definitive, in which case the external armed group obliterates the target-community (Darwin: 2008).

\section{Armed groups within the state}

This brings us to the need of a deeper discussion of the position of AGs within the state. From an essentialist perspective, the AGs do not need the state, whereas the state needs at least one or a collection of AGs to exist, be established and function. Therefore, to deal with AGs within the state is not an intrinsic need of the theory of AGs, but rather a practical expedient given the prevalence of states as contemporary modes of political organization.

For our theory it is not necessary to know who rules in a state, which is a fundamental question of other, less fundamental political theories such as class or gender-based political theory, elite theory and the theory of democracy. Whichever of these theories stands true, in all the cases the existence of the state and its stability are predicated upon and guaranteed by AGs. To a certain extent, this theory is also not concerned with who rules AGs themselves, for this does not impact on their historical role (Schlichte: 2012). States usually rest on a constellation of AGs comprising army, local and national police forces, local militias subordinated to the civilian government and paramilitary forces such as gendarmes, border guards, units of the intelligence services. Where do these groups stand from the perspective of our previous 
classification? I do not think that one can thoroughly classify them in one particular category. Rather, they seem to be oscillating, depending on circumstances, between political-ideological groups and economic-extractive groups.

In peaceful, settled circumstances, even in times of external crises, most of these groups can rightfully be called "extractive". For most of the time the state-supporting AGs act as simple tribute-takers from the community and the elite (they may be argued to be the only category which always extracts money from the economic elites) (Huntington: 1957). Though at these times the AGs can be said to embrace certain ideological features, in peacetime those are virtually indistinguishable from those of the dominant power structures of the states they are protecting. This is not to argue that ideological contamination cannot happen, although the historical record is scant in this case.

Armies and AGs organised in such fashion and in established states are infused with new sets of values and answer to loyalty, order, discipline, authority and laws. In their case the distance between their social function, which remains the same, and the appearances and the commonly held belief in these appearances are possibly the greatest. There is no particular need though for the individual members and sub-groups formed in state-supporting AGs to understand or even admit the basic functions of said AGs. The social role becomes apparent only when tested, and in the case of small intensity tests the reaction of the AGs can be couched in protecting terms such as defending the law, stability and order, in terms of fidelity to the state and its values.

In the complicated case of coups and internal political strife, as long as other AGs do not rise to challenge the established role of state-supporting AGs, their role is murkier. To a certain extent they continue to be extractive groups and except when they splinter on racial, religious or ethnic lines to challenge the territorial make-up of the state the AGs continue to be supporters of sovereignty. AGs could continue to do the bidding of political factions competing for power. Ambitious officers of AGs can themselves become power contenders but despite appearances in most cases the AGs stick to their social functions and do not supplant the central government, even when some branches of the AGs may be seen to overlap certain sectors of government or the economy.

When dealing with non-state supporting AGs who operate within states, one of the first arising questions is whether these types of AGs are in continuous existence after the state-supporting AGs claim and establish a monopoly on legitimate violence. It 
is evident that those directly opposing the pro-government AGs cannot subsist except in a state of civil war, when they are direct competitors in what concerns the understanding and unfolding of sovereignty and legitimacy.

Within a stable state, however, a number of AGs continue their existence. Many of them are of the non-permanent variety, for instance local militias, national guards, regional militias that guard, sometimes against the national government, certain characteristics of an area. This sheer impermanence can be seen as an indication that the components of this particular category of AGs are political in nature, in the sense in which they constitute themselves for fixing a particular problem of the community that derives from an understanding of authority. An example in this category would be vigilantes. Non-permanent, more or less ad-hoc AGs, vigilantes are there to enforce a specific set of rules which are either not-acted upon by the central government, either applied in a different value-system than those of the vigilantes. When vigilantes make justice through armed violence, they impose an authority that is, in spirit, of the same type as that of the state, even when it goes directly against the laws of the state. They enforce, like the state, the views on morality of a dominant group inside a community.

As mentioned before, it is easy to mistake the fact that economic extractive internal AGs have other social functions, like providing their own brand of justice for their communities, or the distribution of produced or looted goods to underprivileged members of a said community. One particularly difficult to understand and classify category are Eric Hobsbawm's primitive rebels, the Robin Hoods, the hajduks robbing those deemed to be rich and redistributing some of the spoils to the local community (Hobsbawm: 1959). Indeed, they are a hybrid from the perspective of our classification. There are undeniable political, ideological reasons for their actions. However these actions fall mostly into the economic-extractive category. Nevertheless, a main reason to classify them as economic internal AGs is precisely the fact that these political motivations are almost never taken to the next level, that of an insurrection against central authority. It is true that these rebels sometimes join armed revolutions, but as long as they do not, they are more into the same type of activity as all bandits are, which is to part someone of their goods through violence or the threat of violence. One should not be blinded by the fact that they do return part of their profits to local communities. This is as much buying protection and support from them as it is distributive justice. Even idealist rebels need to live in a materialistic world. 
Among the "non-legal" internal economic armed groups one counts the mafias and other gangster groups, if they have no full control over any given territory. Otherwise they would accumulate some political characteristics and become internal warlords, which is an interesting border position that should be researched in depth. Mafias, for the purposes of this article, and by mafias we understand here all permanent organised armed criminal groups whose primary activity is extracting economic benefits through means considered illegal by a central government, are easier to approach. The goals, means, intent and actions of these AGs are well known, predictable and researched. So is their relation with local and central authorities, sometimes of deep antagonism but in a number of situations a relation of cooperation. From a theoretical perspective, it is important to underline, once again, the fact that mafias are indeed permanent AGs. Even when their members are unarmed, even when they operate under the guise of respectable businesspersons or tradesmen, the nature of their activity remains intact. There is no taking a holiday or a gap year from that.

One of the main things distinguishing political-ideological AGs is the fact that they cannot exist, unlike other internal AGs, in times of peace, except when they are non-permanent AGs. When they operate as non-permanent AGs, their tactics nearly always inspire modern governments to label them terrorists. Scholars may also do that, with less justice, because essentially the difference between insurgent and terrorist is merely the tactical approach to the revolutionist's situation. An insurgent is all the time up in arms. A terrorist is not, and in this they replicate to a certain extent the conundrum of criminal-type AGs. This raises, of course, the question of whether they can be really non-permanent, as we have argued above that mafias are permanent AGs. But mafias are indeed permanent internal AGs because the extractive activities never cease, whereas it is hard to argue that political struggle is permanent in the long time that may elapse between the actions of some political AGs. Some modern revolutionists would argue that symbolic and ideological struggle is permanent and they may be right to argue that, but from a history-infused perspective the lack of activity, the absence of the propaganda of the deed is problematic.

Insurgents can be more clearly understood as AGs, they are probably the bestresearched AGs so far and therefore they require little efforts of clarification, which have been pursued above.

An interesting problem that should be raised at this juncture is whether there is any substantial difference between internal AGs (those solely confined to the borders of 
a state) and either purely external AGs or internal AGs who also operate from beyond the borders. It is our inclination to believe that the difference is only important from the perspective of the states, which is not something that interests us here. From the viewpoint of the AGs, their reasons of being are not altered by not being confined to the borders of one state. The distinction may have been stronger in the period when there were indeed stateless societies beyond the borders of established states. Marauding bands, invading barbarians, were nevertheless treated by those they attacked or invaded as polities, instead of being labelled as ad-hoc groups put together for reasons of plunder and conquest. The tinted glasses of state-based reflection may have skewed historical perceptions in making us treat as peoples those who might just have been large groups of ethnically and politically unconnected raiders.

Again, these criteria for classification should not be taken as rock solid. Groups can and did switch from one type to another. Impermanent extractive external groups have turned into internal extractive groups dedicated to stability and order. This is in many cases the history of conquests, from China to the Roman Empire. It is not even necessary for the invading extractive group to wholly become the new armed structure of the state, but just an appendage to it, as witnessed by the various groups of Goths and Vandals in the fourth century. More interesting would be the case of an ontological transition within a former internal extractive group from its focus on economic matters to an independence/secessionist/legitimacy-contestant group. This would seem to be the case of Afghan armed tribal factions, who were just extracting resources from their communities and the state, until prompted by foreign invasion to become political groups, focused on the contestation of legitimacy of foreign control (Braithwaite 2013). The reverse situation is also entirely possible. The transition from legitimacycontestation to a focus on resource extraction seems to be a feature of some Latin American guerrillas who have moved from left wing militancy to drug trafficking. Whether these kinds of transitions are permanent remains to be discussed, as so much is in relation to AGs.

\section{Conclusions}

We have argued in this article that the armed group is the fundamental unit of politics, order and the creation and maintaining of society. This essentially establishes that other forms of power are either derived from, rest on or at least suppose the support 
of AGs. The AGs, unlike other political structures, also exist in spaces of no order, of chaos, of loss of control (a circumstance usually called war). Therefore they transcend "normal" politics understood as the peaceful periods in the existence of constituted communities. They can be outsiders, before and between the states. They precede classes and governments and do not need them to exist in order to continue being. In this, they are to be understood as an elementary social structure.

\section{References}

Anderson, B. S., \& Zinsser, J. P. (1989). A History of Their Own. Women in Europe From Prehistory to the Present. Harper \& Row, New York

Army, U. S. (2006). Field Manual 3-24: Counterinsurgency. Headquarters, Department of the Army, Washington, DC: December, 15.

Biro, D. (2010). State-failure or polity-creation? World politics beyond state-centrism. $\mathrm{PhD}$ thesis, Australian National University

Bloch, M. (1940). La société féodale: les classes et le gouvernement des hommes Albin Michel, Paris

Boot, M. (2013). Invisible Armies: An Epic History of Guerrilla Warfare from Ancient Times to the Present. WW Norton \& Company, New York.

Bracamonte, J. A. M., \& Spencer, D. E. (1995). Strategy and tactics of the Salvadoran FMLN guerrillas: last battle of the Cold War, blueprint for future conflicts. Greenwood Publishing Group, Santa Barbara

Braithwaite, R. (2013). Afgantsy: The Russians in Afghanistan 1979-89. Oxford University Press, Oxford

Darwin, J. (2008). After Tamerlane: the rise and fall of global empires, 1400-2000. Penguin UK, London 
Darwin, J. (2009). The empire project: The rise and fall of the British world-system, 1830-1970. Cambridge University Press, Cambridge

Dickie, J. (2014). Cosa Nostra. A History of the Sicilian Mafia. Palgrave, London

Engels, F. (2010). The origin of the family, private property and the state. Penguin UK, London

Le Goff, J. (1964). La civilisation de l'Occident médiéval. Arthaud, Paris

Gump, J. O. (2016). The Dust Rose Like Smoke: The Subjugation of the Zulu and the Sioux. U of Nebraska Press.

Hämäläinen, P. (2008). The Comanche Empire. Yale University Press, New Haven

Heather, P. (2009). Empires and Barbarians. Pan, London

Hobbes, T. (1983(1651)). Leviathan. Dent, London

Hobsbawm, E. J. (1959). Primitive rebels: Studies in archaic forms of social movement in the 19th and 20th centuries. Manchester University Press, Manchester

Huntington, S. P. (1957). The soldier and the state: The theory and politics of civilmilitary relations. Harvard University Press, Boston

Inalcik, H. (2013). The Ottoman Empire: 1300-1600. Hachette UK, Dreadfort

James, L. (1994). The rise and fall of the British Empire. Macmillan, London

Kalyvas, S. N. (2006). The logic of violence in civil war. Cambridge University Press, Cambridge

Kaplan, R. D. (2002). The coming anarchy: Shattering the dreams of the post cold war. Vintage, New York

Kelly, J. D., Jauregui, B., Mitchell, S. T., \& Walton, J. (Eds.). (2010). Anthropology and global counterinsurgency. University of Chicago Press, Chicago

Kilcullen, D. (2010). Counterinsurgency. Oxford University Press, Oxford

Kilcullen, D. (2015). Out of the mountains: The coming age of the urban guerrilla. Oxford University Press, Oxford

Krahmann, E. (Ed.). (2005). New threats and new actors in international security. Springer, Amsterdam

Layton, P. (2015). Bringing the transnational into 'new wars': the case of islamic state. International Review of Social Research, 5(3), 191-201.

Lutz, J., \& Lutz, B. (2013). Global terrorism. Routledge, London

Mantran, R. (1989). Histoire de l'Empire ottoman. Fayard, Paris

Marx, K., \& Engels, F. (2002). The communist manifesto. Penguin, London 
Miroiu, A., \& Ungureanu, R. S. (2015). Armed non-state actors as a distinct research topic. International Review of Social Research, 5(3), 153-155.

Nagl, J. A. (2002). Counterinsurgency lessons from Malaya and Vietnam: Learning to eat soup with a knife. Praeger Publishers, New York

Priestland, D. (2009). The Red Flag: Communism and the making of the modern world. Penguin UK, London

Porch, D. (2013). Counterinsurgency: Exposing the myths of the new way of war. Cambridge University Press, Cambridge

Raufer, X. (1999). New world disorder, new terrorisms: New threats for Europe and the Western World. Terrorism and Political Violence, 11(4), 30-51.

Riley-Smith, J. S. C. (1967). The knights of St. John in Jerusalem and Cyprus, c. 10501310 (pp. 231-33). Macmillan, London

Schlichte, K. (2012). The limits of armed contestation: Power and domination in armed groups. Geoforum, 43(4), 716-724.

Schneckener, U. (2009). Spoilers or governance actors? Engaging armed non-state groups in areas of limited statehood. SBF-Governance Working Paper Series. No. 21 October 2009.

Scott, Joan W. (1986). Gender: A useful category of historical analysis. The American historical review, 91(5), 1053-75.

Syme, R. (2002). The roman revolution. OUP, Oxford.

Tyerman, C. (2006). God's war: a new history of the Crusades. Harvard University Press, Boston

Underwood, P. and Smith, P. in Norwitz, J. H. (2008). Armed Groups: Studies in National Security, Counterterrorism, and Counterinsurgency. Government Printing Office.

Vinci, A. (2008). Armed groups and the balance of power: The international relations of terrorists, warlords and insurgents. Routledge, London

Weber, M. (1978). Economy and society: An outline of interpretive sociology. Univ. of California Press, Los Angeles

Wilkinson, M. (2015). Negotiating with the Other: Centre-Periphery Perceptions, Peacemaking Policies and Pervasive Conflict in the Chittagong Hill Tracts, Bangladesh. International Review of Social Research, 5(3), 179-190. 